\title{
Leaf Gas Exchange and Chlorophyll $a$ Fluorescence in Maize Leaves Infected with Stenocarpella macrospora
}

\author{
Maria Bianney Bermúdez-Cardona, João Américo Wordell Filho, and Fabrício Ávila Rodrigues
}

First and third authors: Universidade Federal de Viçosa, Departamento de Fitopatologia, Laboratório da Interação Planta-Patógeno, Viçosa, Minas Gerais State 36.570-900, Brazil; and second author: Laboratório de Fitossanidade, EPAGRI/CEPAF, Chapecó, Santa Catarina State 89801-970, Brazil.

Current address of M. B. Bermúdez-Cardona: Tolima University, Barrio Santa Helena, Parte Alta A. A. 546, Ibagué-Tolima, Colombia. Accepted for publication 17 June 2014.

\begin{abstract}
Bermúdez-Cardona, M. B., Wordell Filho, J. A., and Rodrigues, F. A. 2015. Leaf gas exchange and chlorophyll $a$ fluorescence in maize leaves infected with Stenocarpella macrospora. Phytopathology 105:26-34.

This study investigated the effect of macrospora leaf spot (MLS), caused by Stenocarpella macrospora, on photosynthetic gas exchange parameters and chlorophyll $a$ fluorescence parameters determined in leaves of plants from two maize cultivars ('ECVSCS155' and 'HIB $32 \mathrm{R} 48 \mathrm{H}^{\prime}$ ) susceptible and highly susceptible, respectively, to $S$. macrospora. MLS severity was significantly lower in the leaves of plants from ECVSCS155 relative to the leaves of plants from HIB 32R48H. In both cultivars, net $\mathrm{CO}_{2}$ assimilation rate, stomatal conductance, and transpira-

significantly increased in inoculated plants of ECVSCS155 and HIB $32 \mathrm{R} 48 \mathrm{H}$, respectively, relative to noninoculated plants. The maximum fluorescence, maximum PSII quantum efficiency, coefficient for photochemical quenching, and electron transport rate significantly decreased in inoculated plants relative to noninoculated plants. For both cultivars, concentrations of total chlorophyll (Chl) $(a+b)$ and carotenoids and the Chl $a / b$ ratio significantly decreased in inoculated plants relative to noninoculated plants. In conclusion, the results from the present study demonstrate, for the first time, that photosynthesis in the leaves of maize plants is dramatically affected during the infection process of $S$. macrospora, and impacts are primarily associated with limitations of a diffusive and biochemical nature.
\end{abstract} tion rate significantly decreased, while the internal to ambient $\mathrm{CO}_{2}$ concentration ratio increased in inoculated plants relative to noninoculated plants. The initial fluorescence and nonphotochemical quenching
Additional keywords: Zea mays.
Maize (Zea mays L.) is one of the world's most important and widely grown cereal crops and serves as a staple human food, feed for livestock, and raw material for many industrial products $(22,34)$. Macrospora leaf spot (MLS), also known as Diplodia leaf streak or spot, caused by the necrotrophic fungus Stenocarpella macrospora (Earle) Sutton (syn. Diplodia macrospora Earle) $(19,33,61)$, is one of the major diseases affecting maize yield worldwide $(2,18,23,40)$, mainly when maize is grown under warm and humid conditions in tropical and subtropical regions $(25,61)$. On leaves, MLS symptoms appear as small, water-soaked lesions $(18,23)$. As the elliptical lesions expand, they become brown in color, with yellow or reddish edges that may have darker concentric rings and contain black structures called pycnidia $(2,18)$. The mycelia and pycnidia of $S$. macrospora can overwinter on maize debris and on seed $(16,50)$. Under warm and moist conditions, conidia are extruded from pycnidia in long cirri and are dispersal by wind, rain, and insects, favoring severe MLS epidemics and great yield losses $(2,15,17,18,33,43)$. The major strategies to control MLS are maize residue management, use of healthy seed, and crop rotation (18). To date, there are no fungicides registered for the control of MLS, and information about the resistance of commercial hybrids is scarce $(3,6,42,45)$.

Pathogens can directly and indirectly affect several physiological processes in their hosts (44). The alteration in the rate of physiological processes in asymptomatic leaf tissue may be pro-

Corresponding author: F. A. Rodrigues; E-mail address: fabricio@ufv.br

http://dx.doi.org/10.1094/PHYTO-04-14-0096-R

(c) 2015 The American Phytopathological Society portional to, proportionally greater than, or proportionally smaller than the corresponding infected leaf tissue caused by a certain disease $(44,57)$. The physiological state of plants infected by pathogens can be investigated in a noninvasive way by the simultaneous measurement of leaf gas exchange and chlorophyll $a$ fluorescence parameters (12). A decrease in the photosynthetic efficiency and stomatal and mesophyll conductance limitations as well as biochemical alterations are the primary effects caused by pathogen infection $(7,12)$. Fungal infection may reduce photosynthesis rates through a number of potential mechanisms: impairment of the functional leaf area and reduction in the photosynthetic efficiency of the remaining green leaf area, as reported for interactions between barley and Rhynchosporium secalis (36) and bean and Colletotrichum lindemuthianum (35); alterations in chloroplasts and a reduction in chlorophyll concentration, as reported in barley leaves infected with Puccinia hordei (44); stomatal closure, as reported in potato leaves infected with Verticillium dahlia (14); and impairment of the photosynthetic apparatus or disruption in photosynthetic metabolic pathways, as reported in poplar leaves infected with Marsonia brunnea f. sp. brunnea (24). Measurement of chlorophyll $a$ fluorescence is an important tool for assessing the photosynthetic performance of the leaves of plants submitted to many types of abiotic and biotic stresses $(5,11,53,56)$. Analysis of chlorophyll $a$ fluorescence is a quantitative measure of both photochemical and nonphotochemical energy dissipation processes occurring in leaves $(30,52)$. Changes in the intensity of chlorophyll $a$ fluorescence in the chloroplasts reflect its functional state (31) and provides important information related to the composition of the pigment systems, excitation energy transfer, physical changes in pigment-protein complexes, primary photochemistry and kinetics, and rates of electron 
transfer reactions in photosystem II (29). Several studies reported that the infection of plants by pathogens often leads to complex alterations in chlorophyll $a$ fluorescence that can be related to changes in the efficiency of photosynthetic processes $(53,56)$. Measurements of chlorophyll $a$ fluorescence have shown that the maximum fluorescence $\left(F_{\mathrm{m}}\right)$, maximum photochemical efficiency of PSII $\left(F_{\mathrm{v}} / F_{\mathrm{m}}\right)$ of dark-adapted leaves, and electron transport rate (ETR) are often decreased during the infection process of pathogens, as described for Phaeoisariopsis griseola and Uromyces appendiculatus in bean (9) and Bremia lactucae in lettuce (49). The fraction of absorbed light energy that was thermally dissipated (nonphotochemical quenching [NPQ]) increased in tomato leaves infected with Oidium neolycopersici (48).

Due to the importance of MLS in decreasing maize yield, and whereas the physiological responses of plants to fungal infection is almost unknown, this study was designed to examine how the infection process of $S$. macrospora could affect the photosynthetic performance of plants using a combination of gas exchange and chlorophyll $a$ fluorescence measurements along with an analysis of chlorophyll pools.

\section{MATERIALS AND METHODS}

Plant cultivation. Maize seeds from 'ECVSCS155' and 'HIB 32R48H', susceptible and highly susceptible, respectively, to $S$. macrospora, were sown in plastic pots containing $2 \mathrm{~kg}$ of Tropstrato (Vida Verde, Mogi Mirim, São Paulo, Brazil) substrate composed of a 1:1:1 mixture of pine bark, peat, and expanded vermiculite. In order to provide phosphorus to the plants, a total of $1.63 \mathrm{~g}$ of calcium phosphate monobasic was added to each plastic pot. In total, five seeds were sown per pot, and each pot was thinned to three seedlings 5 days after seedling emergence. Plants were kept in a greenhouse during the experiments (temperature $28 \pm 2^{\circ} \mathrm{C}$ during the day and $12 \pm 4^{\circ} \mathrm{C}$ at night, relative humidity $70 \pm 5 \%$ ) and were fertilized weekly with $50 \mathrm{ml}$ of a nutrient solution composed of $2.6 \mathrm{mM} \mathrm{KCl}, 0.6 \mathrm{mM} \mathrm{K}_{2} \mathrm{SO}_{4}$, $1.2 \mathrm{mM} \mathrm{MgSO}_{4}, 1.0 \mathrm{mM} \mathrm{CH}_{4} \mathrm{~N}_{2} \mathrm{O}, 1.2 \mathrm{mM} \mathrm{NH}_{4} \mathrm{NO}_{3}, 0.0002 \mathrm{mM}$ $\left(\mathrm{NH}_{4}\right)_{6} \mathrm{Mo}_{7} \mathrm{O}_{24}, 0.03 \mathrm{mM} \mathrm{H} \mathrm{BO}_{4}, 0.04 \mathrm{mM} \mathrm{ZnSO}, 0.01 \mathrm{mM}$ $\mathrm{CuSO}_{4}$, and $0.03 \mathrm{mM} \mathrm{MnCl}_{2}$. The nutrient solution was prepared using deionized water. Plants were watered as needed.

Inoculum production and inoculation procedure. Plants were inoculated with a monosporic isolate of $S$. macrospora (UFV-DFP $S m$ 01) obtained from maize leaves (hybrid HIB $32 \mathrm{R} 48 \mathrm{H}$ ) with MLS symptoms. The isolate of $S$. macrospora was grown in petri dishes containing oat-agar medium and incubated for 35 days in an incubator $\left(22^{\circ} \mathrm{C}\right.$, photoperiod of $12 \mathrm{~h}$ of light and $12 \mathrm{~h}$ of darkness). All of the leaves on each plant of the inoculated treatment were sprayed with a conidial suspension of $S$. macrospora $\left(6 \times 10^{4}\right.$ conidia/ml $)$ at 30 days after emergence (growth stage V5) (10) using a VL Airbrush atomizer (Poasche Airbrush Co, Chicago). Gelatin $\left(1 \% \mathrm{wt} \mathrm{vol}^{-1}\right)$ was added to the suspension to aid conidial adhesion to the leaf blades. The plants of noninoculated controls were sprayed with a solution containing $1 \%$ gelatin without $S$. macrospora conidia. Immediately after application of treatments, all of the plants (both noninoculated and inoculated) were transferred to a growth chamber at $25 \pm$ $2{ }^{\circ} \mathrm{C}, 90 \pm 5 \%$ relative humidity, with a photoperiod of $12 \mathrm{~h}$ of light and $12 \mathrm{~h}$ of darkness for $30 \mathrm{~h}$. After this period, the plants were transferred to a plastic mist growth chamber (MGC) inside a greenhouse for the duration of the experiments. The MGC was made of wood ( $2 \mathrm{~m}$ wide, $1.5 \mathrm{~m}$ high, and $5 \mathrm{~m} \mathrm{long}$ ) and covered with $100-\mu \mathrm{m}$ thick transparent plastic. The temperature inside the MGC ranged from $25 \pm 2{ }^{\circ} \mathrm{C}$ (day) to $20 \pm 2{ }^{\circ} \mathrm{C}$ (night). The relative humidity was maintained at $90 \pm 5 \%$ using a misting system in which nozzles (model NEB-100; KGF Company, São Paulo, Brazil) sprayed mist every $30 \mathrm{~min}$ above the plant canopies. The relative humidity and temperature were measured with a thermo-hygrograph (TH-508, Impac, São Paulo, Brazil).
The maximum natural photon flux density at plant canopy height was $\approx 900 \mu \mathrm{mol} \mathrm{m}{ }^{-2} \mathrm{~s}^{-1}$.

Assessment of MLS severity. The fourth leaf (counted from the base to the top) of each plant per replication of each treatment (18 leaves per treatment, 360leaves per each evaluation time, 180 leaves total) were marked and collected to evaluate MLS severity at 48, 72, 96, 120, and $168 \mathrm{~h}$ after inoculation (hai). The collected leaves were scanned at 300 dpi resolution and the obtained images were processed using QUANT software (58) to obtain severity (chlorosis and necrosis symptoms) values. The area under disease progress curve (AUDPC) for each leaf in each plant was computed using trapezoidal integration of the MLS progress curves over time using the formula proposed by Shaner and Finney (55).

Photosynthetic measurements. The leaf gas exchange parameters were simultaneously determined by conducting the measurements of chlorophyll $a$ fluorescence using a portable open-flow gas exchange system (LI-6400XT; LI-COR Inc., Lincoln, NE) equipped with an integrated fluorescence chamber head (LI-640040; LI-COR Inc.). The net carbon assimilation rate $(A)$, stomatal conductance to water vapor $\left(g_{\mathrm{s}}\right)$, transpiration rate $(E)$, and internal $\left(C_{\mathrm{i}}\right)$ to ambient $\left(C_{\mathrm{a}}\right) \mathrm{CO}_{2}$ concentration ratio $\left(C_{\mathrm{i}} / C_{\mathrm{a}}\right)$ were measured for the fourth leaf of each plant per replication of each treatment at 48, 72, 96, 120, and 168 hai from 10:00 to 13:00 h (solar time), which is when $A$ was at its maximum under artificial PAR (i.e., 1,200 $\mu \mathrm{mol}$ photons $\mathrm{m}^{-2} \mathrm{~s}^{-1}$ at leaf level and $400 \mu \mathrm{mol}$ atmospheric $\mathrm{CO}_{2} \mathrm{~mol}^{-1}$ ). All of the measurements were performed at $25^{\circ} \mathrm{C}$ and the vapor pressure deficit was maintained at $\approx 1.0 \mathrm{kPa}$, while the amount of blue light was set to $10 \%$ of the photosynthetic photon flux density to optimize the stomatal aperture. Previously dark-adapted leaves $(30 \mathrm{~min})$ were illuminated with weak modulated measuring beams $\left(0.03 \mu \mathrm{mol} \mathrm{m} \mathrm{m}^{-2} \mathrm{~s}^{-1}\right)$ to obtain the initial fluorescence $\left(F_{0}\right)$. Saturating white light pulses of $8,000 \mu \mathrm{mol}$ photons $\mathrm{m}^{-2} \mathrm{~s}^{-1}$ were applied for $0.8 \mathrm{~s}$ to ensure maximum fluorescence emissions $\left(F_{\mathrm{m}}\right)$, from which the variable to maximum chlorophyll fluorescence ratio, $\left.F_{\mathrm{v}} / F_{\mathrm{m}}=\left[\left(F_{\mathrm{m}}-F_{0}\right) / F_{\mathrm{m}}\right)\right]$, was calculated. In light-adapted leaves, the steady state fluorescence yield $\left(F_{\mathrm{s}}\right)$ was measured following a saturating white light pulse $\left(8.000 \mu \mathrm{mol} \mathrm{m} \mathrm{m}^{-2} \mathrm{~s}^{-1}, 0.8 \mathrm{~s}\right)$ that was applied to achieve the light-adapted maximum fluorescence $\left(F_{\mathrm{m}}{ }^{\prime}\right)$. The actinic light was then turned off and far-red illumination was applied $\left(2 \mu \mathrm{mol} \mathrm{m} \mathrm{m}^{-2} \mathrm{~s}^{-1}\right)$ to measure the light-adapted initial fluorescence $\left(F_{0}{ }^{\prime}\right)$. Using these parameters, the capture efficiency of the excitation energy by the open PSII reaction centers $\left(F_{\mathrm{v}}{ }^{\prime} / F_{\mathrm{m}}{ }^{\prime}\right)$ was estimated as $F_{\mathrm{v}}{ }^{\prime} / F_{\mathrm{m}}{ }^{\prime}=\left(F_{\mathrm{m}}{ }^{\prime}-F_{0}{ }^{\prime}\right) / F_{\mathrm{m}}{ }^{\prime}$. The coefficient for photochemical quenching $\left(q_{\mathrm{P}}\right)$ was calculated as $q_{\mathrm{P}}=\left(F_{\mathrm{m}}{ }^{\prime}-F_{\mathrm{s}}\right) /\left(F_{\mathrm{m}}{ }^{\prime}-F_{0}{ }^{\prime}\right)$, while that for NPQ was calculated as NPQ $=\left(F_{\mathrm{m}} / F_{\mathrm{m}}{ }^{\prime}\right)-1$. The actual quantum yield of PSII electron transport $\left(\Phi_{\text {PSII }}\right)$ was computed as $\Phi_{\text {PSII }}=\left(F_{\mathrm{m}}{ }^{\prime}-F_{\mathrm{s}}\right) / F_{\mathrm{m}}{ }^{\prime}$, from which the ETR was calculated as $\mathrm{ETR}=\Phi_{\mathrm{PSII}} \cdot \operatorname{PPFD} \cdot f \cdot \alpha$, where $f$ is a factor that accounts for the partitioning of energy between PSII and PSI and is assumed to be 0.5 , which indicates that the excitation energy is distributed equally between the two photosystems, and $\alpha$ is the absorbance by the leaf photosynthetic tissues and is assumed to be 0.84 (37).

Determination of the concentration of photosynthetic pigments. The concentrations of chlorophylls (Chl) $a$ and $b$ and carotenoids were determined using dimethyl sulfoxide (DMSO) as an extractor (54). Five leaf disks (10-mm in diameter) were punched from the fourth leaves at 48, 72, 96, 120, and 168 hai. The collected disks were immersed in glass tubes containing $5 \mathrm{ml}$ of saturated DMSO solution and calcium carbonate $\left(\mathrm{CaCO}_{3}\right)(5 \mathrm{~g}$ liter $^{-1}$ ) (60) and kept in the dark at room temperature for $24 \mathrm{~h}$. The absorbances of the extracts were read at 480,649.1, and $665.1 \mathrm{~nm}$ using a saturated solution of DMSO and $\mathrm{CaCO}_{3}$ as a blank.

Experimental design and data analysis. A two-by-two factorial experiment, consisting of two maize cultivars (ECVSCS155 and HIB $32 \mathrm{R} 48 \mathrm{H}$ ) and noninoculated or inoculated plants was arranged in a completely randomized design with six replications. The experiment was repeated three times. Each experimental unit 
corresponded to a plastic pot containing three plants. In total, 120 plastic pots were used in each experiment (30 plastic pots per treatment at all evaluation times), which equals 18 plants per treatment at each evaluation time. All variables were subjected to an analysis of variance (ANOVA) and the treatment means were compared by Tukey's test $(P \leq 0.05)$ using SAS software (SAS Institute Inc., Cary, NC). For MLS severity, the ANOVA was considered to be a two-by-five factorial experiment, consisting of two maize cultivars and five evaluation times. For the photosynthetic measurements, the concentration of total Chl $(a+b)$, concentration of carotenoids, and the $\mathrm{Chl} a / b$ ratio, ANOVA was considered to be a two-by-two-by-five factorial experiment, consisting of two maize cultivars, noninoculated or inoculated plants, and five evaluation times. For each cultivar, the Pearson correlation was used to determine relationships among the photosynthetic measurements and MLS severity, as well as among the concentration of total Chl $(a+b)$, concentration of carotenoids, and the Chl $a / b$ ratio and MLS severity.

\section{RESULTS}

MLS severity and AUDPC. The factors cultivar and evaluation time as well as their interaction had significant effects $(P \leq 0.05)$ on MLS severity. Cultivar was the only significant factor $(P \leq$ 0.05 ) for AUDPC (Table 1). MLS severity was significantly reduced on the leaves of plants from ECVSCS155 relative to the leaves of plants from HIB 32R48H (Fig. 1A). From 48 to 168 hai, MLS severity increased from 0.5 to $5.1 \%$ on the leaves of plants from ECVSCS155 and from 1.4 to $8.0 \%$ on the leaves of plants from HIB 32R48H. For plants of ECVSCS155, AUDPC was significantly reduced by $34.5 \%$ compared with plants from HIB 32R48H (Fig. 1B).

Photosynthetic parameters. At least one of the evaluated factors (cultivar, plant inoculation, and evaluation time) as well as some of their interactions were significant $(P \leq 0.05)$ for $A, g_{\mathrm{s}}, E$, and $C_{\mathrm{i}} / C_{\mathrm{a}}$. Plant inoculation was the most important factor due to its higher $F$ values, and it explained the variation in all variables

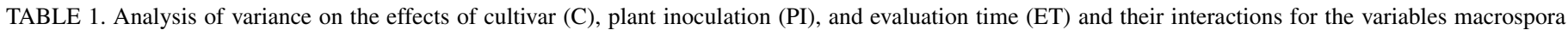

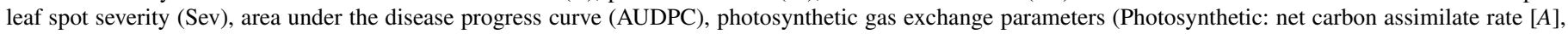

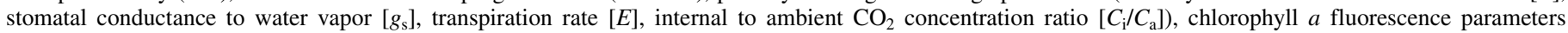

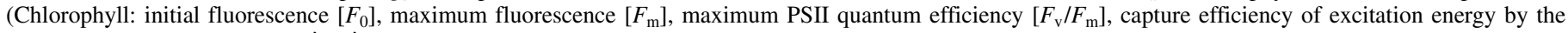

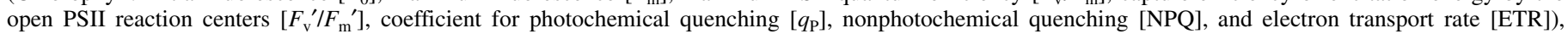
concentrations of total chlorophyll $a+b(\mathrm{Chl})$ and carotenoids (Car), and Chl $a / b$ ratio ${ }^{\mathrm{a}}$

\begin{tabular}{|c|c|c|c|c|c|c|c|}
\hline Variables & $\mathrm{C}$ & PI & ET & $\mathrm{C} \times \mathrm{PI}$ & $\mathrm{C} \times \mathrm{ET}$ & $\mathrm{PI} \times \mathrm{ET}$ & $\mathrm{C} \times \mathrm{PI} \times \mathrm{ET}$ \\
\hline \multicolumn{8}{|c|}{ Disease data } \\
\hline Sev & $<0.001$ & - & $<0.001$ & - & $<0.001$ & - & - \\
\hline AUDPC & $<0.001$ & - & - & - & - & - & - \\
\hline \multicolumn{8}{|c|}{ Photosynthetic } \\
\hline$A$ & 0.011 & $<0.001$ & $<0.001$ & 0.472 & 0.001 & $<0.001$ & 0.002 \\
\hline$g_{\mathrm{s}}$ & $<0.001$ & $<0.001$ & $<0.001$ & $<0.001$ & $<0.001$ & $<0.001$ & 0.001 \\
\hline$E$ & $<0.001$ & $<0.001$ & $<0.001$ & $<0.001$ & $<0.001$ & $<0.001$ & $<0.001$ \\
\hline$C_{\mathrm{i}} / C_{\mathrm{a}}$ & $<0.001$ & $<0.001$ & $<0.001$ & 0.066 & 0.003 & $<0.001$ & 0.076 \\
\hline \multicolumn{8}{|c|}{ Chlorophyll } \\
\hline$F_{0}$ & 0.243 & $<0.001$ & $<0.001$ & 0.020 & 0.270 & $<0.001$ & 0.035 \\
\hline$F_{\mathrm{m}}$ & 0.413 & $<0.001$ & 0.002 & 0.398 & 0.458 & $<0.001$ & 0.771 \\
\hline$F_{\mathrm{v}} / F_{\mathrm{m}}$ & 0.001 & $<0.001$ & $<0.001$ & $<0.001$ & 0.008 & $<0.001$ & $<0.001$ \\
\hline$F_{\mathrm{v}}^{\prime} / F_{\mathrm{m}}^{\prime}$ & $<0.001$ & $<0.001$ & 0.070 & 0.981 & 0.135 & 0.461 & 0.273 \\
\hline$q_{\mathrm{P}}$ & 0.169 & $<0.001$ & $<0.001$ & 0.874 & 0.809 & 0.001 & 0.174 \\
\hline NPQ & 0.002 & $<0.001$ & 0.779 & 0.358 & 0.041 & $<0.001$ & 0.304 \\
\hline ETR & 0.130 & $<0.001$ & $<0.001$ & 0.445 & 0.698 & 0.282 & 0.181 \\
\hline Chl & 0.293 & $<0.001$ & $<0.001$ & 0.272 & 0.671 & $<0.001$ & 0.823 \\
\hline Car & 0.028 & $<0.001$ & $<0.001$ & 0.069 & 0.042 & $<0.001$ & $<0.001$ \\
\hline Chl $a / b$ & 0.006 & $<0.001$ & $<0.001$ & 0.523 & $<0.001$ & $<0.001$ & 0.014 \\
\hline
\end{tabular}

a $F$-based $P$ values.
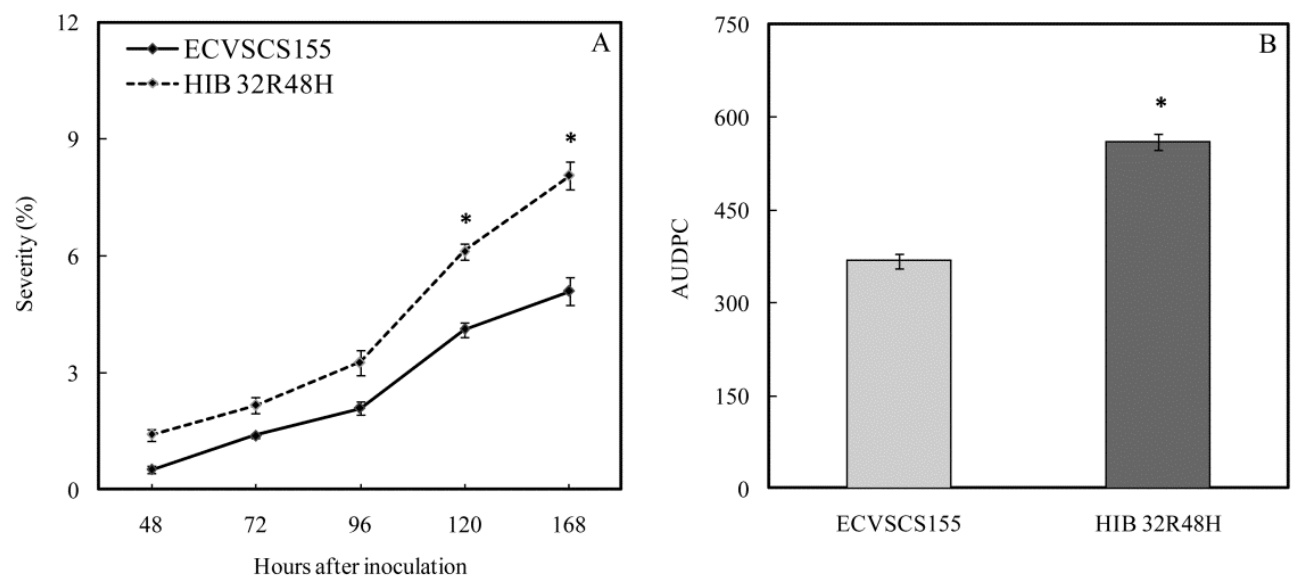

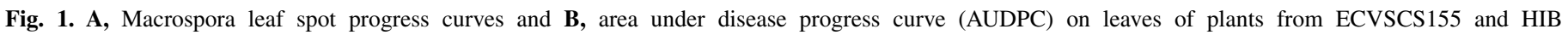

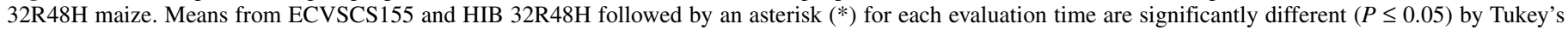

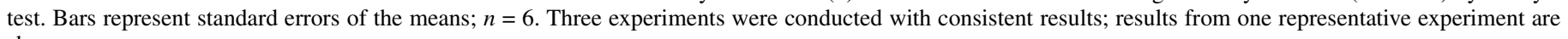
shown. 
evaluated. The interaction cultivar-plant inoculation-evaluation time was significant only for $A, g_{\mathrm{s}}$, and $E$ (Table 1 ).

For both cultivars, $A, g_{\mathrm{s}}$, and $E$ significantly decreased from 48 to 168 hai for inoculated plants relative to their noninoculated counterparts (Fig. 2A to F). Relative to plants of ECVSCS155, reductions in the values of the above parameters were greater at
168 hai for plants of HIB 32R48H, with decreases of 52 and $56 \%$ for $A, 41$ and $49 \%$ for $g_{\text {s }}$ and 41 and $46 \%$ for $E$ in the inoculated plants relative to the noninoculated ones, respectively. For $C_{\mathrm{i}} / C_{\mathrm{a}}$, the highest values occurred in the inoculated plants, with significant differences between noninoculated and inoculated plants of ECVSCS155 occurring at 96 and 168 hai (Fig. 2G). For plants of
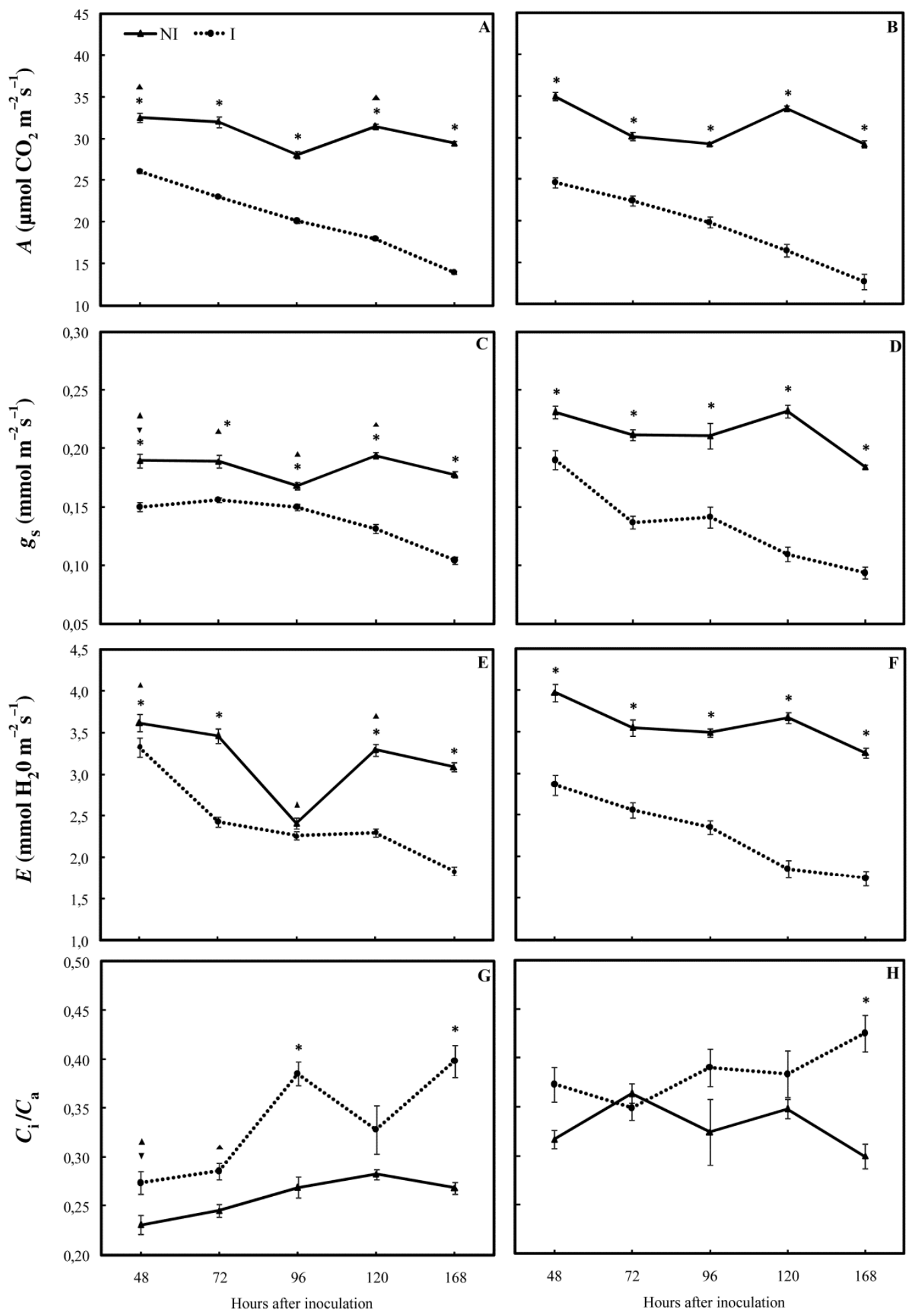

Fig. 2. A and $\mathbf{B}$, Leaf gas exchange parameters, including net carbon assimilation rate $(A)$; $\mathbf{C}$ and $\mathbf{D}$, stomatal conductance to water vapor $\left(g_{\mathrm{s}}\right)$; $\mathbf{E}$ and $\mathbf{F}$, transpiration rate $(E)$; and $\mathbf{G}$ and $\mathbf{H}$, internal to ambient $\mathrm{CO}_{2}$ concentration ratio $\left(C_{\mathrm{i}} / C_{\mathrm{a}}\right)$ determined in leaves of maize plants from ECVSCS155 (A, C, E, and $\left.\mathrm{G}\right)$ and HIB 32R48H (B, D, F, and H) noninoculated (NI) or inoculated (I) with Stenocarpella macrospora. Means for the NI and I treatments for each cultivar followed by an asterisk (*) at each evaluation time are significantly different $(P \leq 0.05)$ by Tukey's test. Symbols $\boldsymbol{\Delta}$ and $\boldsymbol{\nabla}$ indicate differences between ECVSCS155 and HIB 32R48H, respectively, for NI and I treatments at each evaluation time according to Tukey's test $(P \leq 0.05)$. Bars represent standard errors of the means; $n=6$. Three experiments were conducted with consistent results; results from one representative experiment are shown. 
HIB 32R48H, significant differences occurred only at 168 hai (Fig. $2 \mathrm{H}$ ). The $C_{\mathrm{i}} / C_{\mathrm{a}}$ increased by 33 and $30 \%$ at 168 hai for the inoculated plants of ECVSCS155 and HIB 32R48H, respectively, compared with the noninoculated plants.

There were significant differences between noninoculated plants of ECVSCS155 and HIB 32R $48 \mathrm{H}$ in $A, g_{\mathrm{s}}, E$, and $C_{\mathrm{i}} / C_{\mathrm{a}} \cdot A$ was 7 and $6 \%$ higher for plants of HIB 32R $48 \mathrm{H}$ than for plants of ECVSCS155 at 48 and 120 hai, respectively (Fig. 2A and B), and $g_{\mathrm{s}}$ was significantly higher for plants of HIB $32 \mathrm{R} 48 \mathrm{H}$ than for plants of ECVSCS155 at 48 (18\%), 72 (11\%), 96 (20\%), and 120 $(16 \%)$ hai (Fig. 2C and D). $E$ was significantly higher in plants of HIB 32R $48 \mathrm{H}$ than for plants of ECVSCS155 by 9,30 , and $10 \%$ at 48, 96, and 120 hai, respectively (Fig. $2 \mathrm{E}$ and F). $C_{\mathrm{i}} / C_{\mathrm{a}}$ was higher at $48(27 \%)$ and $72(33 \%)$ hai for plants of HIB 32R48H than for plants of ECVSCS155 (Fig. $2 \mathrm{G}$ and $\mathrm{H}$ ); and $g_{\mathrm{s}}$ and $C_{\mathrm{i}} / C_{\mathrm{a}}$ were significantly higher by 21 and $27 \%$, respectively, at 48 hai (Fig. $2 \mathrm{C}, \mathrm{D}, \mathrm{G}$, and $\mathrm{H}$ ) for the inoculated plants of HIB $32 \mathrm{R} 48 \mathrm{H}$ compared with the inoculated plants of ECVSCS155.

Chl $\boldsymbol{a}$ parameters. At least one of the evaluated factors (cultivar, plant inoculation, and evaluation time) as well as some of their interactions were significant $(P \leq 0.05)$ for $F_{0}, F_{\mathrm{m}}, F_{\mathrm{v}} / F_{\mathrm{m}}$, $F_{\mathrm{v}}{ }^{\prime} / F_{\mathrm{m}}{ }^{\prime}, q_{\mathrm{P}}, \mathrm{NPQ}$, and ETR (Table 1$)$. The interaction cultivar- plant inoculation-evaluation time was significant only for $F_{0}$ and $F_{\mathrm{v}} / F_{\mathrm{m}}$ (Table 1 ). At 48 hai, $F_{0}$ significantly increased by 18 and $27 \%$ for inoculated plants of ECVSCS155 and HIB 32R48H, respectively, compared with their noninoculated counterparts (Fig. 3A and B). $F_{\mathrm{m}}, F_{\mathrm{v}} / F_{\mathrm{m}}, q_{\mathrm{P}}$, and ETR significantly decreased in the inoculated plants compared with their noninoculated counterparts (Figs. 3C to F and 4C, D, G, and H). However, the reductions in those parameters were larger at 168 hai for plants of HIB 32R48H than for plants of ECVSCS155, with decreases of 21 and $19 \%$ for $F_{\mathrm{m}}$ (Fig. 3C and D), 22 and $19 \%$ for $q_{\mathrm{P}}$ (Fig. 4C and D), and 31 and $22 \%$ for ETR (Fig. $4 \mathrm{G}$ and $\mathrm{H}$ ). The reductions in $F_{\mathrm{v}} / F_{\mathrm{m}}$ were greater at 96,120 , and 168 hai for plants of HIB $32 \mathrm{R} 48 \mathrm{H}$ than for plants of ECVSCS155, with decreases of 4 and 2,5 and 3 , and 11 and $6 \%$, respectively (Fig. 3E and F). NPQ increased for inoculated plants of both cultivars compared with their noninoculated counterparts (Fig. 4E and F). In plants of HIB 32R48H only, NPQ significantly increased at 120 and 168 hai by 11 and $17 \%$, respectively. In the noninoculated plants, significant differences in $F_{\mathrm{v}} / F_{\mathrm{m}}$ occurred between cultivars at 48 hai (Fig. $3 \mathrm{E}$ and $F$ ). For the inoculated plants, significant differences between cultivars occurred at 168 hai in $F_{\mathrm{v}} / F_{\mathrm{m}}$ (Fig. $3 \mathrm{E}$ and $\mathrm{F}$ ) and at 120 hai in $F_{\mathrm{v}}^{\prime} / F_{\mathrm{m}}{ }^{\prime}$ (Fig. $4 \mathrm{~A}$ and B).
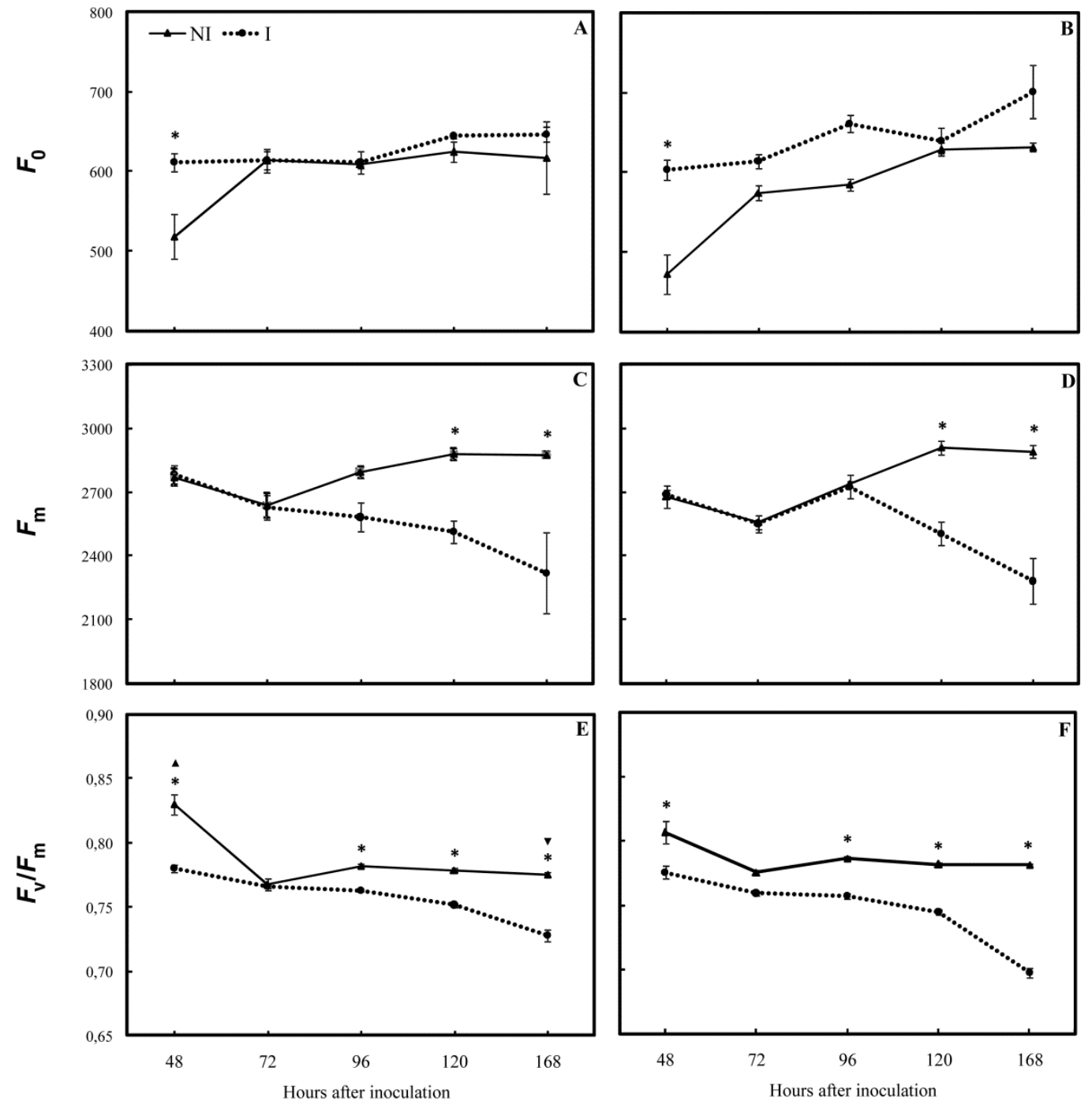

Fig. 3. A and B, Initial fluorescence $\left(F_{0}\right) ; \mathbf{C}$ and $\mathbf{D}$, maximum fluorescence $\left(F_{\mathrm{m}}\right)$; and $\mathbf{E}$ and $\mathbf{F}$, maximum PSII quantum efficiency $\left(F_{\mathrm{v}} / F_{\mathrm{m}}\right)$ determined in leaves of maize plants from ECVSCS155 (A, C, and E) and HIB 32R48H (B, D, and F) noninoculated (NI) or inoculated (I) with Stenocarpella macrospora. Means for the NI and I treatments for each cultivar followed by an asterisk $\left(^{*}\right)$ at each evaluation time are significantly different $(P \leq 0.05)$ by Tukey's test. Symbols $\boldsymbol{\Delta}$ and $\boldsymbol{\nabla}$ indicate differences between ECVSCS155 and HIB 32R48H, respectively, for NI and I treatments at each evaluation time according to Tukey's test $(P \leq 0.05)$. Bars represent standard errors of the means; $n=6$. Three experiments were conducted with consistent results; results from one representative experiment are shown. 
Concentrations of leaf pigments. At least one of the factors examined (cultivar, plant inoculation, and evaluation time) as well as some of their interactions were significant $(P \leq 0.05)$ for the concentrations of total $\mathrm{Chl}(a+b)$ and carotenoids and for the $\mathrm{Chl}$ $a / b$ ratio (Table 1$)$. For both cultivars, concentrations of total Chl $(a+b)$ and carotenoids significantly decreased for the inoculated plants relative to the noninoculated ones. The reduction in total Chl $(a+b)$ concentration was higher for plants of ECVSCS 155 than for plants of HIB 32R48H, with decreases of 58 and $49 \%$, respectively. The reduction in the concentration of carotenoids was higher for plants of HIB $32 \mathrm{R} 48 \mathrm{H}$ than for plants of ECVSCS155, with decreases of 40 and $17 \%$ at 168 hai, re-
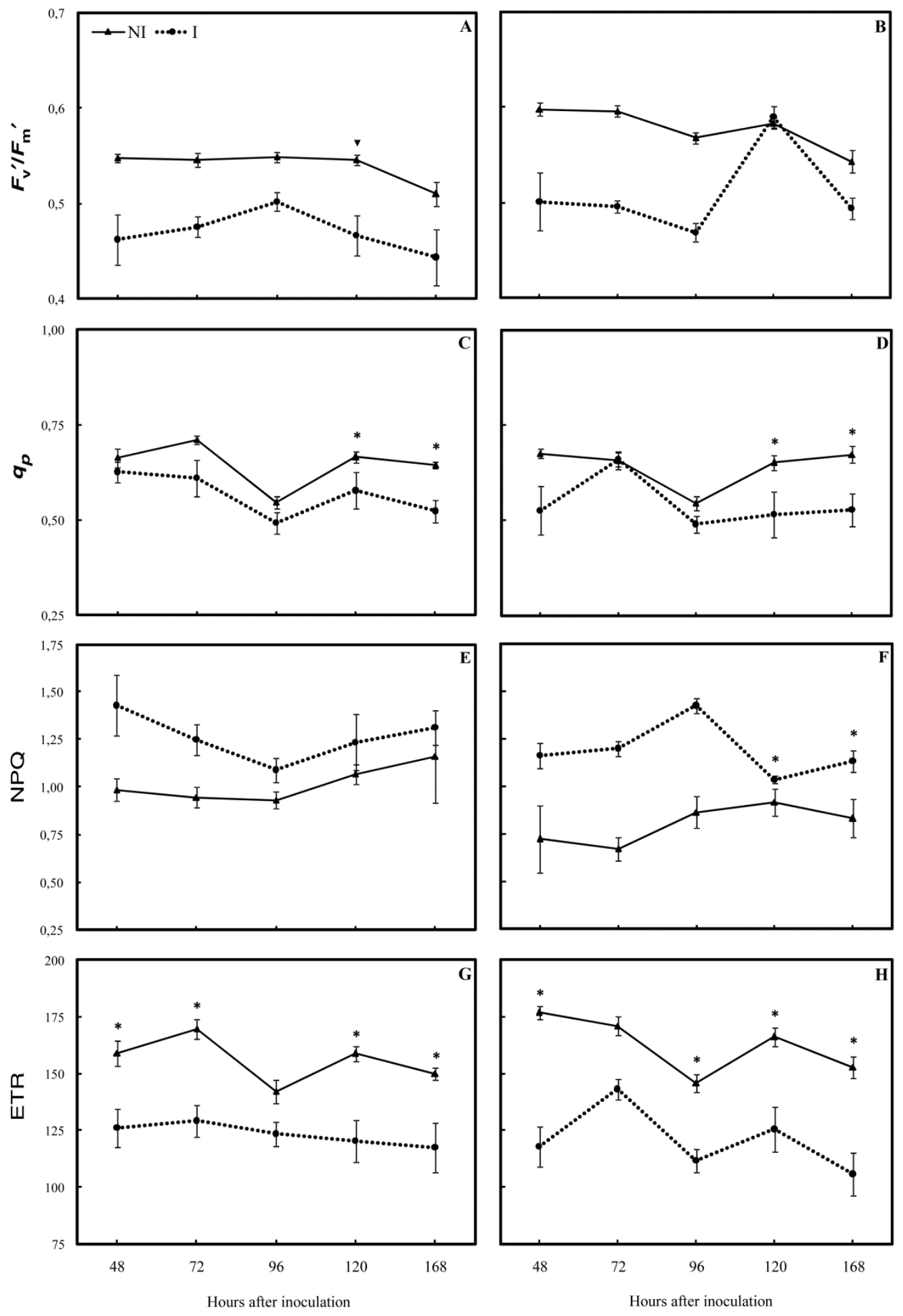

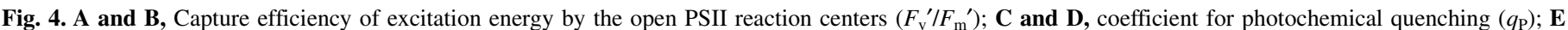

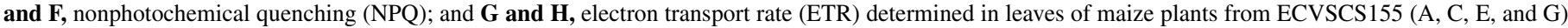

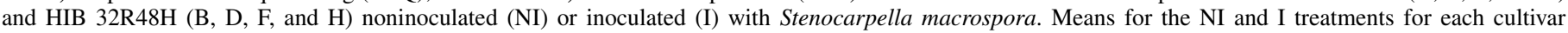

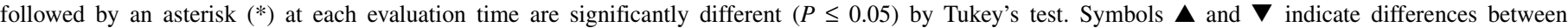

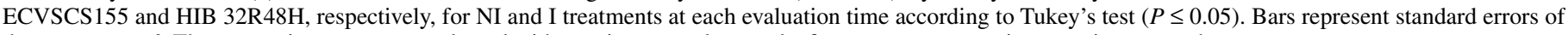
the means; $n=6$. Three experiments were conducted with consistent results; results from one representative experiment are shown. 
spectively. The Chl $a / b$ ratio significantly increased in inoculated plants compared with noninoculated plants of both cultivars.

Pearson correlations. For both cultivars, $A$ was positively correlated with $g_{\mathrm{s}}$ and $E$, and $g_{\mathrm{s}}$ was positively correlated with $E$, but $A, g_{\mathrm{s}}$, and $E$ were negatively correlated with MLS severity (Table 2). In plants of HIB $32 \mathrm{R} 48 \mathrm{H}, C_{\mathrm{i}} / C_{\mathrm{a}}$ was positively correlated with $g_{\mathrm{s}}$ whereas, in plants of ECVSCS155, $C_{\mathrm{i}} / C_{\mathrm{a}}$ was positively correlated with MLS severity (Table 2). For both cultivars, there were significant positive correlations between $F_{\mathrm{v}} / F_{\mathrm{m}}$ and NPQ, total chlorophyll, and carotenoids; between $q_{\mathrm{P}}$ and ETR; and between concentrations of total Chl $(a+b)$ and carotenoids. For both cultivars, significant negative correlations occurred between $F_{\mathrm{v}} / F_{\mathrm{m}}$ and Chl $a / b$ ratio, $F_{\mathrm{v}}{ }^{\prime} / F_{\mathrm{m}}{ }^{\prime}$, and NPQ; between total Chl $(a+b)$ and $\mathrm{Chl} a / b$ ratio; and between Chl $a / b$ ratio and concentration of carotenoids. In both cultivars, $F_{\mathrm{m}}$, $F_{\mathrm{v}} / F_{\mathrm{m}}$, and total $\mathrm{Chl}(a+b)$ concentration were negatively correlated with MLS severity (Table 3 ).

\section{DISCUSSION}

This study provides, to the best of the authors' knowledge, the first evidence of a physiological response associated with the infection by $S$. macrospora on maize leaves. A decrease in photosynthesis caused by pathogen infection has been reported to occur in several plant species $(1,8,9,51,57)$. In the present study, there was a progressive decline in $A, g_{s}$, and $E$ in leaves of inoculated plants compared with leaves of noninoculated plants of both cultivars tested, which was supported by the negative correlation between MLS severity and these parameters. Moreover, the reduction in $A$ at the early stages of fungal infection was proportionally greater than the MLS severity; severity values of 5 to $8 \%$ reduced $A$ by 52 and $56 \%$ at 168 hai for plants of ECVSCS155 and HIB 32R48H, respectively. This finding is in agreement with what was reported for interactions between maize and Phaeosphaeria maydis (28), bean and Colletotrichum lindemuthianum (39), and Eucalyptus globules and Micosphaerella spp. (46). The reduction in $A$ was proportionally greater than was expected from the apparent reduction in green leaf tissue as a result of the pathogen infection and, therefore, indicated that asymptomatic tissue was also affected by fungal infection. Concomitantly, as reported for other necrotrophic pathogens, the decrease in $A$ in maize leaf tissue asymptomatic for MLS may be explained by the secretion of lytic enzymes or non-host selective toxins by $S$. macrospora that easily diffuse into uncolonized leaf tissue, causing maceration and compromising translocation of water and photoassimilates throughout the leaf tissue $(32,38,57,59)$.

The concomitant decrease in both $g_{\mathrm{s}}$ and $E$ during the infection process of $S$. macrospora in the leaf blades of plants of both cultivars may be associated with stomatal closure and is in accordance with reports on interactions between wheat and Puccinia recondita f. sp. tritici (38) and tomato and O. neolycopersici (48). Additionally, in the present study, desiccation of the leaf blades was observed as disease progressed, suggesting that the stomata of the infected leaves were closed to prevent excessive water loss and, therefore, contributed to the observed decrease in $E$ values. Resende et al. (51) reported that $E$ dramatically decreased in sorghum leaves infected by $C$. sublineolum as a method of keeping the stomata closed and maintaining a favorable water status within the leaf blades.

Reductions in $g_{\mathrm{s}}$ are usually associated with decreases in $C_{\mathrm{i}}$ and in $C_{\mathrm{i}} / C_{\mathrm{a}}(21,26,27)$. By contrast, data from the present study showed that, despite a concomitant decrease in $A$ and $g_{\mathrm{s}}$, there was a progressive increase in $C_{\mathrm{i}} / C_{\mathrm{a}}$, which may suggest that the decrease in $A$ cannot be explained solely by reduction in $g_{\mathrm{s}}$ but may also be due to a decrease in mesophyll conductance and impairment of the biochemical capacity of the leaves to adequately assimilate $\mathrm{CO}_{2}$. Reductions in $A$ and $g_{\mathrm{s}}$ related to an increase in $C_{\mathrm{i}} / C_{\mathrm{a}}$ have been reported to occur during interactions between $E$. urophylla and $P$. psidii (1), bean and Uromyces appendiculatus (34), and barley and $R$. secalis (36). According to these authors, the reduction in $A$ was unlikely to have been solely associated with less $\mathrm{CO}_{2}$ entry into leaves but, rather, with some biochemical limitation to $\mathrm{CO}_{2}$ fixation at the chloroplast level. Frequently, alterations in leaf photochemistry and carbon metabolism are related to reduced activity of ribulose bisphosphate carboxylase and changes in the capacity for ribulose bisphosphate regeneration $(39,41)$.

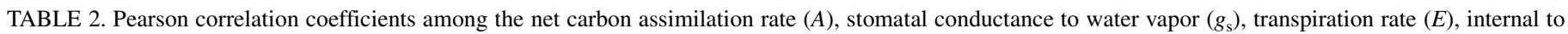
ambient $\mathrm{CO}_{2}$ concentration ratio $\left(C_{\mathrm{i}} / C_{\mathrm{a}}\right)$, and macrospora leaf spot severity $(\mathrm{Sev})$ on the leaves of plants from two maize cultivars ${ }^{\mathrm{a}}$

\begin{tabular}{|c|c|c|c|c|c|}
\hline$\underline{\text { Variables }}$ & $A$ & $g_{\mathrm{s}}$ & $E$ & $C_{\mathrm{i}} / C_{\mathrm{a}}$ & $\mathrm{Sev}$ \\
\hline$A$ & $\cdots$ & $0.781 * *$ & $0.729 * *$ & -0.391 & $-0.867 * *$ \\
\hline$g_{\mathrm{s}}$ & $0.753 * *$ & $\ldots$ & $0.743 * *$ & 0.255 & $-0.608 * *$ \\
\hline$E$ & $0.762 * *$ & $0.643 * *$ & $\ldots$ & -0.033 & $-0.551 * *$ \\
\hline$C_{\mathrm{i}} / C_{\mathrm{a}}$ & -0.239 & $0.425 * *$ & -0.106 & $\ldots$ & $0.462^{*}$ \\
\hline Sev & $-0.870 * *$ & $-0.617 * *$ & $-0.571 * *$ & 0.240 & $\ldots$ \\
\hline
\end{tabular}

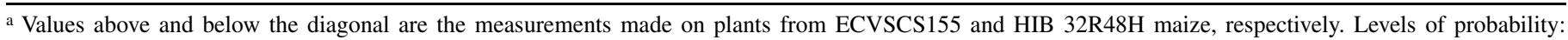
$*=0.05$ and $* *=0.01$.

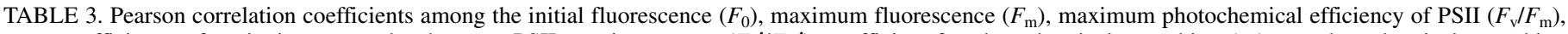

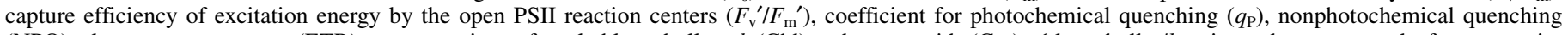

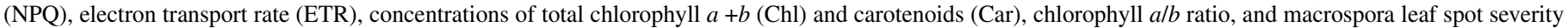
(Sev) on the leaves of plants from two maize cultivars ${ }^{\mathrm{a}}$

\begin{tabular}{|c|c|c|c|c|c|c|c|c|c|c|c|}
\hline Variables & $F_{0}$ & $F_{\mathrm{m}}$ & $F_{\mathrm{v}} / F_{\mathrm{m}}$ & $F_{\mathrm{v}}{ }^{\prime} / F_{\mathrm{m}}{ }^{\prime}$ & $q_{\mathrm{P}}$ & NPQ & ETR & Chl & Chl $a / b$ & Car & $\mathrm{Sev}$ \\
\hline$F_{0}$ & & $0.757 * *$ & 0.137 & 0.055 & -0.267 & $0.455^{*}$ & -0.165 & -0.036 & 0.024 & -0.022 & 0.110 \\
\hline$F_{\mathrm{m}}$ & 0.205 & $\ldots$ & $0.747 * *$ & 0.041 & 0.085 & 0.164 & 0.066 & $0.493^{*}$ & -0.276 & 0.398 & $-0.460 *$ \\
\hline$F_{\mathrm{v}} / F_{\mathrm{m}}$ & $-0.615^{* *}$ & $0.641 * *$ & $\ldots$ & -0.001 & 0.383 & $0.407 *$ & 0.247 & $0.778 * *$ & $-0.430 *$ & $0.480^{*}$ & $-0.814^{* *}$ \\
\hline$F_{\mathrm{v}}^{\prime} / F_{\mathrm{m}}{ }^{\prime}$ & -0.049 & -0.141 & 0.043 & $\ldots$ & 0.021 & $-0.591^{* *}$ & $0.689 * *$ & -0.248 & 0.251 & -0.396 & -0.140 \\
\hline$q_{\mathrm{P}}$ & -0.355 & 0.027 & 0.301 & $-0.456^{*}$ & $\ldots$ & 0.039 & $0.721 * *$ & $0.420^{*}$ & -0.165 & 0.349 & $-0.501^{*}$ \\
\hline NPQ & -0.273 & 0.353 & $0.665^{* *}$ & $-0.447 *$ & 0.330 & $\ldots$ & $-0.484^{*}$ & 0.306 & -0.289 & 0.360 & 0.006 \\
\hline ETR & -0.308 & -0.083 & 0.209 & 0.273 & $0.692 * *$ & -0.069 & $\ldots$ & 0.119 & 0.059 & -0.024 & $-0.451 *$ \\
\hline Chl & $0.546^{* *}$ & 0.248 & $0.625 * *$ & -0.188 & 0.294 & 0.129 & 0.212 & $\ldots$ & $-0.796 * *$ & $0.855^{* *}$ & $-0.718^{* *}$ \\
\hline Chl $a / b$ & $0.565 * *$ & $-0.402 *$ & $-0.763^{* *}$ & 0.115 & -0.148 & -0.207 & -0.071 & $-0.827 * *$ & $\ldots$ & $-0.876^{* *}$ & 0.361 \\
\hline Car & $-0.477 * *$ & 0.386 & $0.668 * *$ & -0.331 & 0.304 & 0.271 & 0.108 & $0.918 * *$ & $-0.941 * *$ & $\ldots$ & 0.396 \\
\hline Sev & $0.401 *$ & $-0.615^{* *}$ & $-0.814 * *$ & 0.142 & -0.371 & -0.089 & 0.288 & $-0.591 * *$ & $0.749 * *$ & $-0.683^{* *} *$ & $\ldots$ \\
\hline
\end{tabular}

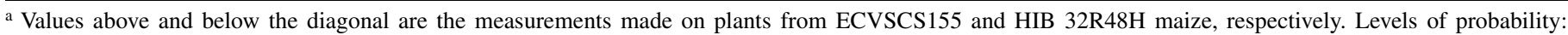
$*=0.05$ and $* *=0.01$. 
Regardless of the maize cultivar, both $F_{0}$ and NPQ tended to be higher in the leaves of inoculated plants than in the leaves of noninoculated plants, suggesting that the PSII reaction centers were somehow damaged or that the transfer of excitation energy from the antenna to the reaction center was impaired $(4,13,37)$. According to Plazek et al. (47), an increase in the $F_{0}$ values on barley leaves infected with Bipolaris sorokimiana was an indicator of antenna damage.

Despite the observed increases in NPQ values, the nonphotochemical dissipation was insufficient to avoid photoinhibitory damage, which was indicated by decreases in $F_{\mathrm{m}}$ and $F_{\mathrm{v}} / F_{\mathrm{m}}$ values in the leaves of inoculated plants from both cultivars and was also supported by the negative correlations of $F_{\mathrm{m}}$ and $F_{\mathrm{v}} / F_{\mathrm{m}}$ with MLS severity. ETR and $q_{\mathrm{P}}$ decreased in the leaves of inoculated plants of both cultivars, as indicated by the negative correlations of ETR and $q_{\mathrm{P}}$ with MLS severity. The observed decreases in $q_{\mathrm{P}}$ could be related to increases in the fraction of reduced $\mathrm{Q}_{\mathrm{A}}\left(\mathrm{Q}_{\mathrm{A}}^{-}\right)$in PSII, which indicates an increased possibility for photoinhibition to be affected (4) and, therefore, the electron transport chain to PSI via the cytochrome $b_{6} / f$ complex and plastocyanin (13). Additionally, the decreases in $F_{\mathrm{v}} / F_{\mathrm{m}}$ were accompanied by decreases in $F_{\mathrm{v}}{ }^{\prime} / F_{\mathrm{m}}{ }^{\prime}$, suggesting that the ability of the $S$. macrospora-infected leaves to capture and to transfer collected energy was dramatically compromised.

The concentration of pigments was negatively affected in the leaves of inoculated plants from both cultivars as the MLS progressed. The concentration of total Chl $(a+b)$ decreased with the progress of MLS, which may have led to an increase in the $\mathrm{Chl} a / b$ ratio. The reduction in chlorophyll concentration could be associated with the action of lytic enzymes and non-host selective toxins released in the infected tissues by $S$. macrospora, in accordance with reports on maize leaves infected with Exserohilum turcicum (20). Additionally, the decrease in total Chl $(a+b)$ concentration would lead to a reduction in the ability and the efficiency of the leaves to capture the energy required for the photochemical reactions in photosynthesis (20).

In conclusion, the results from the present study demonstrate, for the first time, that photosynthesis in the leaves of maize plants is dramatically affected during the infection process of $S$. macrospora, and impacts are primarily associated with limitations of a diffusive and biochemical nature.

\section{ACKNOWLEDGMENTS}

F. A. Rodrigues thanks the National Council for Technological and Scientific Development (CNPq) for his fellowship. M. B. BermúdezCardona was supported by the "Programa de Estudante-Convênio de PósGraduação" (PEC-PG) from CAPES and also by the Scholarship Program of the Tolima University, Colômbia. This study was supported by grants from CAPES, CNPq, and the Fundação de Amparo a Pesquisa do Estado de Minas Gerais (FAPEMIG) to F. A. Rodrigues. We thank D. Rezende and C. E. Aucique-Perez for their technical assistance.

\section{LITERATURE CITED}

1. Alves, A. A., Guimarães, L. M. S., Chaves, A. R. M., DaMatta, F. M., and Alfenas, A. C. 2011. Leaf gas exchange and chlorophyll $a$ fluorescence of Eucalyptus urophylla in response to Puccinia psidii infection. Acta Physiol. Plant. 33:1831-1839.

2. Anderson, B., and White, D. G. 1987. Fungi associated with corn stalks in Illinois in 1982 and 1983. Plant Dis. 71:135-137.

3. Anderson, B., and White, D. G. 1994. Evaluation of methods for identification of corn genotypes with stalk rot and lodging resistance. Plant Dis. 78:590-593.

4. Baker, N. R. 2008. Chlorophyll fluorescence: A probe of photosynthesis in vivo. Annu. Rev. Plant Biol. 59:89-113.

5. Baker, N. R., Oxborough, K., Lawson, T., and Morison, J. I. L. 2001. High resolution imaging of photosynthetic activities of tissues, cells and chloroplast in leaves. J. Exp. Bot. 52:615-621.

6. Bampi, D., Casa, R. T., Bogo, A., Sangoi, L., Sachs, C., Bolzan, J. M., and Piletti, G. 2012. Fungicide performance on the control of Macrospora leaf spot in corn. Summa Phytopathol. 38:319-322.

7. Barón, M., Flexas, J., and Delucia, E. H. 2012. Photosynthetic responses to biotic stress. Pages 331-351 in: Terrestrial Photosynthesis in a Changing Environment: A Molecular, Physiological, and Ecological Approach. J. Flexas, F. Loreto, and H. Medrano, eds. Cambridge University Press, Cambridge, United Kingdom.

8. Bassanezi, R. B., Amorim, L., and Bergamin Filho, A. 2000. Análise das trocas gasosas em feijoeiro com ferrugem, mancha angular e antracnose. Fitopatol. Bras. 25:643-650.

9. Bassanezi, R. B., Amorim, L., Bergamin Filho, A., and Berger, R. D. 2002. Gas exchange and emission of chlorophyll fluorescence during the monocycle of rust, angular leaf spot and anthracnose on bean leaves as a function of their trophic characteristics. J. Phytopathol. 150:37-47.

10. Bensch, M. J., Van Staden, J., and Rijkenberg, F. H. J. 1992. Time and site inoculation of maize for optimum infection of ears by Stenocarpella maydis. J. Phytopathol. 136:265-269.

11. Berger, S., Papadopoulos, M., Schreiber, U., Kaiser, W., and Roitsch, T. 2004. Complex regulation of genes expression, photosynthesis and sugar levels by pathogen infection in tomato. Physiol. Plant. 122:419-428.

12. Berger, S., Sinha, A. K., and Roitsch, T. 2007. Plant physiology meets phytopathology: Plant primary metabolism and plant-pathogen interactions. J. Exp. Bot. 58:4019-4026.

13. Bolhàr-Nordenkampf, H. R., Long, S. P., Baker, N. R., Oquist, G., Schreibers, U., and Lechner, E. G. 1989. Chlorophyll fluorescence as a probe of the photosynthetic competence of leaves in the field: A review of current instrumentation. Funct. Ecol. 3:497-515.

14. Bowden, R. L., Rouse, D. L., and Sharkey, T. D. 1990. Mechanism of photosynthesis decrease by Verticillium dahliae in potato. Plant Physiol. 94:1048-1055.

15. Bradley, C. A., Pedersen, D. K., Zhang, G. R., and Pataky, N. R. 2010. Occurrences of Diplodia leaf streak caused by Stenocarpella macrospora on corn (Zea mays) in Illinois. Plant Dis. 94:1262.

16. Casa, R. T., Reis, E. M., and Zambolim, L. 2003. Decomposição dos restos culturais do milho e sobrevivência saprofítica de Stenocarpella macrospora e Stenocarpella maydis. Fitopatol. Bras. 28:355-361.

17. Casa, R. T., Reis, E. M., and Zambolim, L. 2004. Dispersão vertical e horizontal de conídios de Stenocarpella macrospora e Stenocarpella maydis. Fitopatol. Bras. 29:141-147.

18. Casa, R. T., Reis, E. M., and Zambolim, L. 2006. Doenças do milho causadas por fungos do gênero Stenocarpella. Fitopatol. Bras. 31:427439.

19. Casa, R. T., Zambolim, L., and Reis, E. M. 1998. Transmissão e controle de Diplodia em sementes de milho. Fitopatol. Bras. 23:436-441.

20. Chauhan, R. S., Singh, B. M., and Develash, R. K. 1997. Effect of toxic compounds of Exserohilum turcicum on chlorophyll content, callus growth and cell viability of susceptible and resistant inbred lines of maize. J. Phytopathol. 145:435-440.

21. Chaves, M. M., Flexas, J., and Pinheiro, C. 2009. Photosynthesis under drought and salt stress: Regulation mechanisms from whole plant to cell. Ann. Bot. 103:551-560.

22. CIMMYT, 2012. Maize Annual Report: Research Program on Maize. CGIAR, International Maize and Wheat Improvement Center, Mexico, D.F., Mexico.

23. Dai, K., Nagai, M., Sasaki, H., Nakamura, H., Tachechi, K., and Warabi, M. 1987. Detection of Diplodia maydis (Berkeley) Saccardo from imported corn seed. Res. Bull. Plant Prot. Serv. 23:1-6.

24. Erickson, J. E., Stanosz, G. R., and Kruger, E. L. 2003. Photosynthetic consequences of marssonina leaf spot differ between two poplar hybrids. New Phytol. 161:577-583.

25. Flett, B. C., and Wehner, F. C. 1991. Incidence of Stenocarpella and Fusarium cob rots in monoculture maize under different tillage systems. J. Phytopathol. 133:327-333.

26. Flexas, J., Diaz-Espejo, A., Galmés, J., Kaldenhoff, R., Medrano, H., and Ribas-Carbo, M. 2007. Rapid variations of mesophyll conductance in response to changes in $\mathrm{CO}_{2}$ concentration around leaves. Plant Cell Environ. 30:1284-1298.

27. Flexas, J., Ribas-Carbó, M., Bota, J., Galmés, J., Henkle, M., MartínezCañellas, S., and Medrano, H. 2006. Decreased rubisco activity during water stress is not induced by decreased relative water content but related to conditions of low stomatal conductance and chloroplast $\mathrm{CO}_{2}$ concentration. New Phytol. 172:73-82.

28. Godoy, C. V., Amorin, L., and Bergamin Filho, A. 2001. Alterações na fotossíntese e na transpiração de folhas de milho infetadas por Phaeosphaeria maydis. Fitopatol. Bras. 26:209-215.

29. Govindjee. 2004. Chlorophyll $a$ fluorescence: A bit of basic and history. Pages 1-42 in: Chlorophyll a Fluorescence: A Signature of Photosynthesis. G. C. Papageorgiou and Govindgee, eds. Springer Publishing Company, New York.

30. Kramer, D M., Johnson, G., Kirats, O., and Edwards, G. E. 2004. New fluorescence parameters for the determination of $\mathrm{Q}_{\mathrm{A}}$ redox state and 
excitation energy fluxes. Photosynth. Res. 79:209-218.

31. Krause, G. H., and Weis, E. 1991. Chlorophyll fluorescence and photosynthesis: The basics. Annu. Rev. Plant Physiol. Plant Mol. Biol. 42:313349.

32. Laluk, K., and Mengiste, T. 2010. Necrotroph attacks on plants: Wanton destruction or covert extortion? Arabidopsis Book 12:1-34.

33. Latterell, F. M., and Rossi, A. E. 1983. Stenocarpella macrospora (=Diplodia macrospora) and $S$. maydis $(=D$. maydis) compared as pathogens of corn. Plant Dis. 67:725-729.

34. Lobell, D. B., Cassman, K. G., and Field, C. B. 2009. Crop yield gaps: Their importance, magnitudes and causes. Annu. Rev. Environ. Resour. 34:179-204.

35. Lopes, D. B., and Berger, R. D. 2001. The effects of rust and anthracnose on the photosynthetic competence of diseased bean leaves. Phytopathology 91:212-220.

36. Martin, P. J. 1986. Gaseous exchanges studies of barley leaves infected with Rhynchosporium secalis (Oudem) J. J. Davis. Physiol. Mol. Plant Pathol. 28:3-14.

37. Maxwell, K., and Johnson, G. N. 2000. Chlorophyll fluorescenceA practical guide. J. Exp. Bot. 51:659-668.

38. McGrath, M. T., and Pennypacker, S. P. 1990. Alteration of physiological processes in wheat flag leaves caused by stem rust and leaf rust. Phytopathology 80:677-686.

39. Meyer, S., Saccardy-Adjl, K., Rizza, F., and Genty, B. 2001. Inhibition of photosynthesis by Colletotrichum lindemuthianum in bean leaves determined by chlorophyll fluorescence imaging. Plant Cell Environ. 24:947-955.

40. Muimba, K. A., and Bergstrom, G. C. 2011. Reduced anthracnose stalk rot in resistant maize is associated with restricted development of Colletotrichum graminicola in pith tissues. J. Phytopathol. 159:329-341.

41. Nogués, S., Cotxarrera, L., Alegre, L., and Trillas, M. I. 2002. Limitations to photosynthesis in tomato leaves induced by Fusarium wilt. New Phytol. 154:461-470.

42. Olatinwo, R., Cardwell, K., Menkin, A., Deadman, M., and Julian, A. 1999. Inheritance of resistance to Stenocarpella macrospora (Earle) ear rot of maize in the mid-altitude zone of Nigeria. Eur. J. Plant Pathol. 105:535-543

43. Olatinwo, R. O., Cardwell, K. F., Deadman, M. L., and Julian, A. M. 1999. Epidemiology of Stenocarpella macrospora (Earle) sutton on maize in the midaltitude zone of Nigeria. J. Phytopathol. 147:347-352.

44. Owera, S. A. P., Farrar, J. F., and Whitbread, R. 1981. Growth and photosynthesis in barley infected with brown rust. Physiol. Plant Pathol. 18:79-90.

45. Piletti, G. J., Casa, R. T., Bampi, D., Piletti, L. M. M.S., Stoltz, J. C., Sangoi, L., and Michelutti, D. 2014. Resistance of corn hybrids to macrospora leaf spot. Summa Phytopathol. 40:24-28.

46. Pinkard, E. A., and Mohammed, C. L. 2006. Photosynthesis of Eucalyptus globulus with Mycosphaerella leaf disease. New Phytol. 170:119-127.

47. Plazek, A., Rapacz, M., and Hura, K. 2004. Relationship between quantum efficiency of PSII and cold-induced plant resistance to fungal pathogens. Acta Physiol. Plant. 26:141-148.

48. Prokopová, J., Mieslerová, B., Hlavácková, V., Hlavinka, J., Lebeda, A., Naus, J., and Spundová, M. 2010. Changes in photosynthesis of Lycopersicon spp. plants induced by tomato powdery mildew infection in combination with hear shock pre-treatment. Physiol. Mol. Plant Pathol. $74: 205-213$

49. Prokopová, J., Spundová, M., Sedlárová, M., Husicková, A., Novotný, R., Doleizal, K., Naus, J., and Lebeda, A. 2010. Photosynthetic responses of lettuce to downy mildew infection and cytokinin treatment. Plant Physiol. Biochem. 48:716-723.

50. Reis, E. M., and Mario, J. L. 2003. Quantification of Diplodia macrospora and D. maydis inoculum in crop residues, in the air, and its relationship with infection of corn kernels. Fitopatol. Bras. 28:143-147.

51. Resende, R. S., Rodrigues, F. A., Cavatte, P. C., Martins, S. C. V., Moreira, W. R., Chaves, A. R. M., and DaMatta, F. M. 2012. Leaf gas exchanges and oxidative stress in sorghum plants supplied with silicon and infected by Colletotrichum sublineolum. Phytopathology 102:892898.

52. Rohácek, K. 2002. Chlorophyll fluorescence parameters: The definitions, photosynthetic meaning, and mutual relationships. Photosynthetica 40:1329 .

53. Rolfe, S. A., and Scholes, J. D. 2010. Chlorophyll fluorescence imaging of plant-pathogen interaction. Protoplasma 247:163-175.

54. Santos, R. P., Cruz, A. C. F., Iarema, L., Kuki, K. N., and Otoni, W. C. 2008. Protocolo para extração de pigmentos foliares em porta-enxertos de videira micropropagados. Ceres 55:356-364.

55. Shaner, G., and Finney, R. E. 1977. The effect of nitrogen fertilization on the expression of slow-mildewing resistance in Knox wheat. Phytopathology 67:1051-1056.

56. Sholes, J. D., and Rolfe, S. A. 2009. Chlorophyll fluorescence imaging as tool for understanding the impact of fungal diseases on plant performance: A phenomics perspective. Funct. Plant Biol. 36:880-892.

57. Shtienberg, D. 1992. Effects of foliar diseases on gas exchanges processes: A comparative study. Phytopathology 82:760-765.

58. Vale, F. X. R., Fernandes Filho, E. I., and Liberato, J. R. 2003. A software plant disease severity assessment. In: 8th Int. Cong. Plant Pathol. Vol. 2. Christchurch, New Zealand.

59. van Kan, J. A. L. 2006. Licensed to kill: The lifestyle of a necrotrophic plant pathogen. Trends Plant Sci. 11:248-253.

60. Wellburn, A. R. 1994. The spectral determination of chlorophylls $a$ and $b$, as well as total carotenoids, using various solvents with spectrophotometers of different resolution. J. Plant Physiol. 144:307-313.

61. White, D. G. 1999. Compendium of Corn Diseases, 3rd ed. The American Phytopathological Society, St. Paul, MN. 